\title{
Nicotinic receptor abnormalities in Alzheimer's and Parkinson's diseases
}

\author{
E K PERRY,,$*$ R H PERRY,$*$ C J SMITH,$*$ D J DICK, $†$ J M CANDY $\ddagger$ J A EDWARDSON, \\ A FAIRBAIRN, $\|$ G BLESSED $\S$
}

From the Department of Neuropathology,* Regional Neurological Centre, $\dagger$ MRC Neuroendocrinology Unit, $\ddagger$ Psychogeriatric Unit,§ Newcastle General Hospital, and St Nicholas Hospital, \| Newcastle-upon-Tyne, UK

SUMMARY The status of cholinergic receptors in dementia is related to the question of potential cholinergic therapy. Whilst muscarinic receptor binding is generally reported to be normal or near normal, findings are reported which indicate substantial reductions of hippocampal nicotinic (high affinity nicotine) binding (occurring in conjunction with decreased choline acetyltransferase) in both Alzheimer's and Parkinson's but not Huntington's diseases. A further indication that nicotinic receptor function may be abnormal in Alzheimer's disease is the extensive loss of an endogenous compound, detected for the first time in human brain, which inhibits normal nicotinic binding. Both receptor binding and the inhibitor are also substantially decreased with increasing age in the normal hippocampus.

In diseases, such as Alzheimer's, associated with extensive reduction in pre-synaptic cholinergic activity ${ }^{1}$ the status of cholinergic muscarinic and nicotinic receptors is still uncertain. Most investigations of the muscarinic receptor indicate that binding is unchanged in Alzheimer's disease although reduced total antagonist binding, selective reductions in the M2 site and moderate reductions in both $\mathrm{M} 1$ and $\mathrm{M} 2$ sites have variously been reported. ${ }^{2-6}$ With respect to nicotinic sites, previous measurements of $\alpha$-bungarotoxin binding in Alzheimer's disease ${ }^{7,8}$ can be questioned on the basis of a dissociation between the nicotinic receptor and toxin binding in the CNS. ${ }^{9}$ Recent evidence of a close anatomical correlation between the non-muscarinic binding of acetylcholine and high affinity nicotine binding in the brain ${ }^{10}$ suggests that nicotine (as opposed to a $\alpha$-bungarotoxin) can be employed to detect cerebral nicotinic receptors. In one previous investigation of Alzheimer's disease $^{4}$ nicotine binding was reported to be de-

Address for reprint requests: Dr EK Perry, Regional Neurological Centre, Newcastle General Hospital, Westgate Road, Newcastleupon-Tyne NE4 6BE, UK.

Received 11 July 1986 and in revised form 6 November 1986. Accepted 13 November 1986 creased in certain subcortical areas but not the cortex, possibly reflecting the technical limitations of using unwashed membranes ${ }^{4}$ which may contain a receptor inhibitor (see below). A later report ${ }^{11}$ has indicated extensive reductions of both $(3 \mathrm{H})$ acetylcholine and (3H) nicotine binding to washed cortical membranes in Alzheimer's disease.

In the present investigation the nicotinic receptor has been quantified using the binding of $\left({ }^{3} \mathrm{H}\right)$ nicotine to washed hippocampal membranes, prepared postmortem from clinically and pathologically assessed patients with Alzheimer's and Parkinson's diseases, both manifesting substantial pre-synaptic cholinergic deficits. In addition to the receptor itself, the inhibition by soluble hippocampal extracts of $(3 \mathrm{H})$ nicotine binding to normal membranes, indicative of the presence of a "nicotine-like" endogenous ligand (other than acetylcholine), ${ }^{12}$ was also measured.

\section{Methods}

Cases, matched for age and autopsy delay (table), were selected according to strict clinical and pathological criteria previously outlined ${ }^{13,14}$ and included normal subjects (with no neurological or psychiatric disorder), and patients with Alzheimer's disease, Parkinson's disease (both with and without dementia) and Huntington's disease. Numerous cortical senile plaques and neurofibrillary tangles were seen 
Table 1 Nicotinic receptor binding activities in the human hippocampus

\begin{tabular}{|c|c|c|c|c|c|}
\hline & \multirow[b]{2}{*}{ Normal } & \multirow{2}{*}{$\begin{array}{l}\text { Alzheimer's } \\
\text { disease }\end{array}$} & \multicolumn{2}{|c|}{ Parkinson's disease } & \multirow[b]{3}{*}{ Huntington's disease } \\
\hline & & & Non-demented & Demented & \\
\hline & mean $\pm S D$ & & & & \\
\hline \multirow{4}{*}{$\begin{array}{l}\left({ }^{3} \mathrm{H}\right) \text { nicotine binding } \\
\text { (fmol/mg protein) } \\
\text { Nicotine binding inhibitort } \\
\text { (\% inhibition at } 40 \mathrm{mg} / \mathrm{ml} \text { ) } \\
\text { Choline acetyltransferase } \\
\text { (nmol/h/mg protein) } \\
\text { Number of cases } \\
\text { Age (yr) } \\
\text { Autopsy delay (h) }\end{array}$} & $10 \cdot 5 \pm 4.4$ & $5 \cdot 2 \pm 3 \cdot 4 \|$ & $6.2 \pm 3.2 \S$ & $6.6 \pm 1.6 \ddagger$ & $8.0 \pm 1.6$ \\
\hline & $24.5 \pm 12.5$ & $6.6 \pm 7 \cdot 8 \|$ & $22.9 \pm 14.9$ & $30 \cdot 6 \pm 20 \cdot 7$ & $31.5 \pm 10.6$ \\
\hline & $14.9 \pm 5.2$ & $3.6 \pm 2.79$ & $7.9 \pm 2.4 \|$ & $2.5 \pm 3.19$ & $16 \cdot 3 \pm 1 \cdot 3$ \\
\hline & $\begin{array}{l}11 \\
69 \pm 10 \\
42 \pm 15\end{array}$ & $\begin{array}{l}8 \\
76 \pm 11 \\
39 \pm 27\end{array}$ & $\begin{array}{l}7 \\
73 \pm 7 \\
47 \pm 28\end{array}$ & $\begin{array}{l}45 \\
75 \pm 8 \\
47 \pm 22\end{array}$ & $\begin{array}{l}4 \\
67 \pm 9 \\
21 \pm 15\end{array}$ \\
\hline
\end{tabular}

* Scatchard analyses of pooled normal and Alzheimer tissue from the adjacent hippocampal gyrus (hippocampal tissue availability being restricted) indicated that the receptor abnormality in Alzheimer's disease reflects a reduction in $B \max$ rather than $K_{\mathrm{p}}$. B max values, obtained from computer fitting of the curvilinear Scatchard plot to a two-side model, were 0.57 and $32.80 \mathrm{fmol} / 10 \mathrm{mg}$ tissue in Alzheimer's disease compared with 2.39 and $86.22 \mathrm{fmol} / 10 \mathrm{mg}$ tissue in the normal (high and low affinity sites, respectively, $\mathrm{K}_{\mathrm{D}}$ values for the high affinity site being 1.00 and $1.48 \mathrm{nM}$ in the Alzheimer and normal, respectively).

fFor the receptor inhibitor, $\mathrm{IC}_{\text {so }}$ values for pooled hippocampal extracts were 87 and $31 \mathrm{mg}$ (original weight)/ml in the Alzheimer and normal groups respectively.

‡. , $\|, \uparrow$ : significantly different from the normal (Mann Whitney $U$ test), $p<0.05,0.02,0.01$ and 0.001 .

in only the Alzheimer cases ${ }^{13}$ and in the neurologically normal group there were no neuropathological abnormalities.

Membranes were prepared from frozen hippocampal tissue, homogenised in $10 \% \mathrm{w} / \mathrm{v}$ sodium phosphate buffer $(10 \mathrm{mM}, \mathrm{pH} 7 \cdot 4)$, centrifuged $\left(40,000 \mathrm{~g}, 15 \mathrm{~min}, 4^{\circ} \mathrm{C}\right)$ and washed twice, a procedure judged to remove endogenous inhibitor on the basis of unchanged receptor binding beyond the first wash. Nicotinic binding was estimated by resuspending membranes $(10 \mathrm{mg}$ original weight $/ \mathrm{ml} 50 \mathrm{mM}$ Tris buffer, $\mathrm{pH} \mathrm{7.4)}$ and incubating for $20 \mathrm{~min}$. at $25^{\circ} \mathrm{C}$ with $4 \mathrm{nM}$ L-(N-methyl- $\left.{ }^{3} \mathrm{H}\right)$-nicotine (New England Nuclear) in the absence and presence of $0.1 \mathrm{mM}(-)$-nicotine di-(+)tartrate (to detect non-specific binding). ${ }^{10}$ Labelled membranes were separated by ultra-filtration through GF/C filters pre-soaked in $\mathbf{0} \cdot 1 \%$ poly-lysine. ${ }^{4}$ Under these conditions specific $(3 \mathrm{H})$ nicotine binding ranged from $50-70 \%$ of the total binding.

The nicotine binding inhibitor ${ }^{12}$ was estimated in the supernatant fraction from the original homogenate by measuring nicotine binding to thalamic membranes (selected for relatively high receptor binding) in the presence and absence of supernatant (the tissue concentration being selected to give under $70 \%$ inhibition, on the basis of a linear relation between concentration and inhibition up to $75 \%$ ).

Choline acetyltransferase activity and protein were estimated in aliquots of the original homogenate, as previously described. ${ }^{13}$

\section{Results}

The mean level of $(3 \mathrm{H})$ nicotine binding in the hippocampus was within the range of activities previously reported for archicortical and neocortical structures in the human brain postmortem. ${ }^{4,11}$ Compared with the normal group, nicotinic receptor binding was, together with choline acetyltransferase, reduced in both Alzheimer's and Parkinson's diseases (the latter including cases with and without dementia) but not in
Huntington's chorea (table). Moreover, assessment of the endogenous nicotine binding inhibitor revealed a significant decrease of this compound in Alzheimer's disease. The inhibition by soluble hippocampal extracts from control and diseased individuals of nicotine binding to normal human thalamic membranes (selected on the basis of the relatively high binding in this area) was substantially (over $70 \%$ ) reduced in $\mathrm{Al}$ zheimer's disease but not the other groups (table). Scatchard and IC50 analyses conducted on pooled samples (hippocampal material being insufficient for individual analyses) indicated (table) that the decrease in both receptor binding and the binding inhibitor in Alzheimer's disease reflected reductions in the number, rather than affinities, of these molecules.

Neither the receptor nor the inhibitor were, as previously reported ${ }^{4,11}$ related to the delay between death and autopsy $(r=-0.28$ and 0.04 , respectively, within the normal group) although both were substantially affected by age. Thus, within an extended neurologically normal group, aged between $\mathbf{4 0}$ and 90 years, there was a striking and significant decline in both aspects of nicotinic activity with increasing age (fig).In the combined normal, Alzheimer and Parkinson groups (table) there was a significant correlation $(r=0.49, p<0.01)$ between receptor binding and enzyme activity.

\section{Discussion}

The present observations of a reduction in nicotinic binding in Alzheimer's disease are consistent with one previous report on washed cortical membranes ${ }^{11}$ and provide new data suggesting similar reductions occur in Parkinson's disease. The receptor reduction in pa- 
thological conditions involving cholinergic degeneration (decreased choline acetyltransferase as in Alzheimer's and Parkinson's diseases, table, and Down's syndrome, unpublished observation) but not in those with normal cortical cholinergic activity (Huntington's disease, table, and motoneuron disease, unpublished observation) suggests the receptor is at least partly associated with cholinergic innervation. In the rat, ${ }^{15}$ fimbria transection is accompanied by an increase in hippocampal nicotinic $\left({ }^{3} \mathrm{H}\right)$ acetylcholine binding which, although inconsistent with the present observations, may reflect a species difference or the relatively non-selective nature of experimental fimbria lesions compared with the pathological condition.

The reduction in the endogenous nicotinic in hibitor, reported for the first time in Alzheimer's disease, is greater than the receptor abnormality itself (table) and may be more specifically associated with the disease process. It is unlikely that the inhibitor loss is due to non-specific influences such as drug treatment or mode of death since these were similar in the Huntington's disease group. Moreover, preliminary data in Down's syndrome indicate inhibitor reductions in older cases (50-60 yr, with Alzheimertype pathology) but not a younger ( $31 \mathrm{yr}$ ) case. Together with the normality of the inhibitor in the Alzheimer caudate nucleus (unpublished observation) this suggests a possible association with intrinsic cortical pathology (for example plaques and tangles) not seen in the cases of Parkinson's disease examined, in which the inhibitor was normal (table). The chemical nature of the inhibitor remains to be determined. Our findings agree with a previous report ${ }^{12}$ that it is heat resistant and of low molecular weight (under 10,000 daltons). Its anatomical distribution, being relatively concentrated in cortical compared with striatal regions (unpublished observation), suggests it is not acetylcholine or choline.

The status of the cortical nicotinic receptor and particularly the nature of the inhibitor (a putative endogenous modulator of this receptor) should clearly be investigated further in relation to the normal pro- $\triangle$ cess of aging and in dementing or cognitive disorders such as Alzheimer's and Parkinson's diseases. With respect to normal behaviour, whilst the effects of drugs interacting with the muscarinic cholinergic receptor have been widely investigated (antagonists and agonists generally impairing and enhancing (respectively) memory and information processing) effects of nicotine on such mental functions are less clear. Alterations in arousal ${ }^{16}$ and the acquisition of avoidance behaviour ${ }^{17}$ in animals have been reported and in man nicotine has the opposite effect to scopolamine (a muscarinic antagonist) in performance involving rapid information processing. ${ }^{18}$ Long-term administration of nicotine in experimental animals is reported to increase both the behavioural stimulation effect of nicotine and nicotinic binding of acetylcholine in, amongst other areas, cerebral cortex. ${ }^{19}$ If a similar effect were obtained in Alzheimer's disease, then given the low number of binding sites and reduction in a nicotine-like factor in this disorder, nicotine might be worth testing therapeutically.

This investigation was financially supported by the Medical Research Council and Astra, and Dr Carol Whitford kindly performed the Scatchard analyses. 


\section{References}

1 Perry EK. The cholinergic hypothesis-ten years on. $\mathrm{Br}$ Med Bull 1986;42:63-69.

2 Davies P, Verth AH. Regional distribution of muscarinic acetylcholine receptors in normal and Alzheimer's type dementia brains. Brain Res 1977;138:385-92.

3 White P, Hiley CR, Goodhart MJ, et al. Neocortical cholinergic neurons in elderly people. Lancet 1977;1:668-70.

4 Shimohama S, Taniguchi T, Fujiwara M, Kameyama M. Changes in nicotinic and muscarinic cholinergic receptors in Alzheimer type dementia. $J$ Neurochem, 1986;46:288-93.

5 Mash DC, Flynn DD, Potter LT. Loss of M2 muscarinic receptors in the cerebral cortex in Alzheimer's disease, and experimental cholinergic denervation. Science 1985;228:1115-7.

6 Candy JM, Fairbairn AF, Johnson M, Perry EK, Perry RH, Smith C. Hippocampal cholinergic muscarinic and putative nicotinic receptors in human cognitive disorders. Br J Pharmacol 1986;88:359.

7 Davies P, Feisullin S. Postmortem stability of $\alpha$ bungarotoxin binding sites in mouse and human brain. Brain Res 1981;216:449-54.

8 Lang W, Henke $H$. Cholinergic receptor binding and autoradiography in brains of non-neurological and senile dementia of Alzheimer type patients. Brain Res 1983;267:271-80.

9 Oswald RE, Freeman JA. Alpha-bungarotoxin binding and central nervous system nicotinic acetylcholine receptors. Neuroscience 1981;6:1-14.

10 Clarke PBS, Schwartz RD, Paul SM, Pert CB, Pert A. Nicotinic binding in rat brain: autoradiographic com- parison of $(3 \mathrm{H})$ acetylcholine, $(3 \mathrm{H})$ nicotine and (121I) alpha bungarotoxin. $J$ Neuroscience 1985;5:1307-15.

11 Whitehouse PJ, Martino AM, Antuono PG, et al. Nicotinic acetylcholine binding sites in Alzheimer disease. Brain Res 1986;371:146-51.

12 Sershen H, Reith MEA, Hashim A, Lajtha A. Endogenous material in brain inhibiting $(3 \mathrm{H})$ nicotine and (3H) acetylcholine binding. J Neurosci Res 1984; 12:563-9.

13 Perry EK, Curtis M, Dick DJ, et al. Cholinergic correlates of cognitive impairment in Parkinson's disease: comparisons with Alzheimer's disease. J Neurol Neurosurg Psychiatry 1985;48:413-21.

14 Perry EK, Tomlinson BE, Blessed G, et al. Correlation of cholinergic abnormality with senile plaques and mental test scores in senile dementia. $\mathrm{Br}$ Med $J$ 1978;2:1457-9.

15 Morrow AL, Loy R, Creese I. Alteration of nicotinic cholinergic agonist binding sites in hippocampus after fimbria transection. Brain Res 1985;334:309-14.

16 Rosencrans JA. Effects of nicotine on behavioural arousal and brain 5-hydroxytryptamine function in female rats selected for differences in activity. Eur $J$ Pharmacol 1971;14:29-37.

17 Essman WB. Changes in cholinergic activity and avoidance behaviour by nicotine in differentially housed mice. Int $J$ Neuroscience 1971;2:199-205.

18 Wesnes K, Warburton DM. Effects of scopolamine and nicotine on human rapid information processing performance. Psychopharmacol 1984;82:147-50.

19 Schwartz RD, Kellar KJ. In vivo regulation of $(3 \mathrm{H})$ acetylcholine recognition sites in brain by nicotinic cholinergic drugs. J Neurochem 1985;45:427-33. 